\title{
PENGARUH AIR RENDAMAN KULIT BATANG PEPAYA TERHADAP KEMATIAN JENTIK AEDES AEGYPTI PADA TEMPAT PENAMPUNGAN AIR DI KECAMATAN CURUP TENGAH
}

\author{
Rustam Aji \\ (Prodi Keperawatan Curup Poltekkes Kemenkes Bengkulu)
}

\begin{abstract}
The Aedes aegypti larva which is not monitored develops into an adult mosquito, causing Dengue Fever. Eradication using fogging, abate powder, has an effect on the environment. Researchers are looking for a safe and effective natural larvicidal solution using papaya plants. Papaya plants contain the enzyme papain substance, the effect of papain protease can kill the larva of Aedes aegypti. This study aims to determine the effect of water soaking papaya bark on the death of Aedes egypti larvae. Research location in Curup Tengah District. Quasi-experimental type, Chi-square analysis, calculating odds ratio, Chi-square test. Approximately (94.4\%) there were 34 dead larvae, a small portion (5.5\%) had 2 live larvae, from 36 larvae of Aedes aegypti in $50 \mathrm{ml}$ of water soaking the papaya bark under 1 minute. Chi-square analysis results $P$ value $=0.04<\alpha 0.05$, there is a significant effect of water soaking papaya bark on larvae death of Aedes aegypti. The value of $p$ value $=0.043$, has the influence of water soaking papaya bark, odds ratio $=4.10$ times. It is expected that the community will play a role in eradicating the larva of Aedes aegypti, by making a marinade of papaya bark poured into a water reservoir
\end{abstract}

Keywords: Papaya bark, larvae of Aedes aegypti

\begin{abstract}
Abstrak
Jentik Aedes aegypti yang tidak terpantau berkembang menjadi nyamuk dewasa, menyebabkan penyakit Demam Berdarah. Pemberantasan menggunakan fogging, serbuk abate, memiliki efek terhadap lingkungan. Peneliti mencari solusi larvasida alami yang aman dan efektif menggunakan tumbuhan pepaya. Tumbuhan pepaya mengandung zat enzim papain, efek protease papain dapat membunuh jentik Aedes aegypti. Penelitian ini bertujuan mengetahui pengaruh air rendaman kulit batang pepaya terhadap kematian jentik Aedes egypti. Lokasi penelitian di Kecamatan Curup Tengah. Jenis quasi eksperimental, analisis Chi-square, menghitung odds ratio, uji Chi kuadrat. Sekitar (94,4\%) ada 34 jentik mati, sebagian kecil (5,5\%) ada 2 jentik hidup, dari 36 jentik Aedes aegypti dalam rendaman $50 \mathrm{ml}$ air rendaman kulit batang pepaya waktu dibawah 1 menit. Hasil analisis Chi-square nilai $P$ value $=0.04<\alpha 0.05$, ada pengaruh signifikan air rendaman kulit batang pepaya terhadap kematian jentik Aedes aegypti. Nilai $p$ value $=0.043$, mempunyai pengaruh air rendaman kulit batang pepaya, odds ratio $=4,10$ kali. Diharapkan masyarakat berperan dalam pemberantasan jentik Aedes aegypti, dengan membuat rendaman kulit batang pepaya dituang ke penampungan air.
\end{abstract}

Kata Kunci : Kulit batang pepaya, Jentik Aedes aegypti. 


\section{PENDAHULUAN}

Jentik Aedes aegypti apabila tidak terpantau akan terus berkembang menjadi nyamuk dewasa, apabila nyamuk mengandung Aedes aegypti, bisa menyebabkan penyakit Demam Berdarah dengue (DBD) pada manusia yang terhisap darahnya oleh nyamuk tersebut.

DBD merupakan masalah kesehatan. Penularan DBD ditentukan oleh keberadaan Jentik nyamuk Aedes aegypti. Cara efektif untuk menanggulangi penyakit DBD dengan memutuskan siklus hidup vektor penyakit DBD, yaitu dengan cara membunuh keberadaan Jentik nyamuk Aedes aegypti, yang selama ini menggunakan fogging, serbuk abate dan lain sebagainya yang memiliki efek samping terhadap lingkungan.

Peneliti mencari solusi larvasida alami yang aman dan efektif, karena peneliti melihat banyaknya tumbuhan pepaya yang ditanam oleh warga di pekarangan rumah. Tumbuhan pepaya banyak mengandung zat yang disebut papain, efek protease papain dapat membunuh Jentik Aedes aegypti. Pohon Pepaya (Carica papaya, Linn.) Familia (Cariccaceae). Papaw (Inggris), Pepaya (Indonesia), Gedang (Sunda); Betik, Kates, Telo gantung (Jawa). Fadlilah Nur Angger Luhung, dkk (2017)

Pepaya (Carica papaya) merupakan tumbuhan yang berbatang tegak dan basah. Pepaya menyerupai palma, bunganya berwarna putih dan buahnya yang masak berwarna kuning kemerahan, rasanya seperti buah melon. Tinggi pohon pepaya dapat mencapai 8 sampai 10 meter dengan akar yang kuat. Tanaman ini juga dibudidayakan di kebun-kebun luas karena buahnya yang segar dan bergizi. Tumbuhan pepaya banyak mengandung zat yang disebut enzim papain, efek protease papain dapat membunuh larva Aedes aegypti. Astriani Yoke, (2016)

Penelitian ini bertujuan mengetahui pemberian air rendaman kulit batang pepaya terhadap kematian jentik nyamuk Aedes aegypti pada tempat penampungan air.Lokasi penelitian di Kecamatan Curup Tengah jumlah rumah yang disurvei sebanyak 36 Jentik pada tempat penampungan air.

Survei yang dilakukan peneliti di sekitar pekarangan rumah warga Kecamatan Curup Tengah banyak terdapat tumbuhan pepaya, ketika peneliti mengobservasi tempat penampungan air ada yang tidak ditutup, hal ini dikhawatirkan menjadi tempat pemkembangan jentik Aedes Aegypti, keberadaan jentik Aedes aegypti sangat menentukan untuk pengendalian perkembangan nyamuk DBD dan jentik Aedes aegypti dan dapat digunakan sebagai indikator untuk menentukan angka bebas jentik di suatu daerah perlu disosialisasikan pemanfaatan rendaman kulit batang pepaya untuk meminimalisir keberadaan jentik Aedes aegypti. Tujuan Penelitian Penelitian ini untuk mengetahui : Pengaruh air rendaman kulit batang pepaya terhadap kematian jentik Aedes Aegypti pada tempat penampungan air." 


\section{METODE PENELITIAN}

Jenis penelitian ini bersifat quasi eksperimental yaitu penelitian yang mendekati percobaan sesungguhnya, untuk mengetahui efek pemberian air rendaman kulit batang pepaya yang efektif sebagai repellent kematian jentik Aedes aegypti. Variabel dependen, yaitu jumlah dan persentase larva yang mati, dan jumlah dan persentase larva yang hidup.Variabel independennya yaitu pemberian rendaman kulit batang pepaya, dianalisis dengan menggunakan tabulasi silang $2 \times 2$, menghitung odds ratio, dan uji Chi kuadrat. Sampel objek penelitian 36 jentik Aedes aegypti. Pelaksanaan penelitian 4 (empat) bulan.

Analisis yang digunakan adalah univariat untuk mengetahui efek pemberian air rendaman kulit batang pepaya terhadap kematian jentik Aedes aegypti dan proporsi masingmasing setiap variabel yang diteili. Analisis bivariat untuk mengetahui pengaruh variabel independen dan dependen.Alat Dan Bahan Penelitian Peneliti menggunakan beberapa alat sebagai berikut : Pisau, gunting, tangguk jaring halus, senter, botol kaca kecil, pipet plastik, piring putih, gelas ukur, gayung, korek, kompor gas, panci, stopwach, jam, alat tulis dan kertas observasi. Peneliti menggunakan beberapa bahan penelitian sebagai berikut antara lain kulit batang pepaya, air dan jentik Aedes aegypti.Proses cara pembuatan rendaman kulit batang pepaya sebagai berikut : 1.Siapkan air 2 gelas belimbing atau sebanyak $400 \mathrm{ml}$. 2.Ambil 3 potong kulit batang pepaya dicuci bersih selanjutnya dipotongpotong.3.Potongan kulit batang pepaya, dimasukkan kedalam alat tabung rendaman masing-masing yang berisi $200 \mathrm{ml}$ air kemudian di proses sehingga menjadi air rendaman kulit batang pepaya.4.Selanjutnya air rendaman kulit batang pepaya di beri lebel, kemudian masukkan rendaman kulit batang pepaya dengan ukuran50 ml, pada dua botol kaca kecil kedalam air yang ada jentik Aedes aegypti nya.

Cara kerja pengambilan jentik Aedes aegypti, sebagai berikut :1.Jentik Aedes aegypti diamblil dari 36 tempat penampungan air di rumah warga masyarakat Kelurahan Batu Galing.2.Menggunakan senter sebagai penerang, untuk melihat dan memastikan tempat penampungan air yang ada jentiknya.3.Apabila jentik Aedes aegypti ditemukan dengan menggunakan tangguk jaring halus, selanjutnya jentik diambil dengan pipet plastik.4.Kemudian jentik Aedes aegypti yang hidup di masukkan masing-masing kedalam dua piring putih berisi air.Pelaksanaan prosedur penelitian sebagai berikut : 1. Siapkan seluruh peralatan dan bahan-bahan yang diperlukan.2.Ambil masing-masing botol kaca kecil yang berisi air rendaman kulit batang pepaya yang berisi $50 \mathrm{ml}$ air yang didinginkan.3.Siapkan stopwach atau jam, alat tulis dan kertas observasi.4.Kemudian ambil larva hidup dengan menggunakan pipet plastik dari piring putih yang berisi air, dipilih masing-masing jentik Aedes aegypti.5.Masukkan masing-masing jentik hidup ke dalam 
botol yang berisi masing-masing $50 \mathrm{ml}$ air rendaman kulit batang pepaya.6 Ambil stopwach / jam dan amati jentik yang mati didalam botol pada masing-masing rendaman air rendaman kulit batang pepaya.7.Kemudian catat jentik Aedes aegypti yang mati karena rendaman air rendaman kulit batang pepaya.8.Tabulasi data yang didapat kemudian dianalisa sesuai dengan metode statistik yang digunakan.

Data yang diperoleh dari hasil observasi terlebih dahulu dianalisa menggunakan desain cross sectional study, dianalisis dengan menggunakan tabulasi silang $2 \times 2$, mengetahui efek pemberian air rendaman kulit batang pepaya terhadap kematian jentik Aedes aegypti dan menghitung odds ratio, dan uji Chi kuadrat. dengan tingkat kemaknaaan 0,05. Tolak Ho jika $p<(0,05)$. (Nursalam, 2003).

\section{HASIL PENELITIAN}

\section{Hasil Analisis Univariat}

Kegiatan dalam penelitian ini meliputi perhitungan jumlah kematian jentik Aedes aegypti dengan efek air rendaman kulit batang pepaya, setelah perlakuan. Proses pengamatan pada 36 jentik Aedes aegypti yang direndam dalam air rendaman kulit batang pepaya selama maksimal 5 menit, pada masing-masing jentik yang mati maupun hidup, yang berada di dalam botol berisi masing-masing $50 \mathrm{ml}$ air rendaman kulit batang pepaya, maka didapatkan hasil seperti pada tabel berikut :

\section{Tabel 1. Pengaruh Pemberian Air Rendaman Kulit Batang Pepaya terhadap Kematian Jentik Aedes aegypti.}

\begin{tabular}{lllllll}
\hline Pemberian air & \multicolumn{5}{c}{ Kematian jentik nyamuk Aedes aegypti } \\
\hline rendaman kulit & & Mati & \multicolumn{3}{c}{ Hidup } & Total \\
\hline batang pepaya & $\mathrm{n}$ & $\%$ & $\mathrm{n}$ & $\%$ & $\mathrm{n}$ & $\%$ \\
\hline Ya & 34 & 94.4 & 2 & 5,5 & 36 & 100 \\
\hline Tidak & 0 & 0 & 36 & 100 & 36 & 100 \\
\hline
\end{tabular}

Berdasarkan Tabel.1 diatas, menunjukkan bahwa hampir seluruh $(94,4 \%)$ ditemukan 34 jentik mati dan tersisa 2 jentik yang hidup dari jumlah 36 jentik nyamuk Aedes aegypti $(\mathrm{Ae})$ dalam air rendaman kulit batang pepaya $50 \mathrm{ml}$ dalam waktu dibawah 1 menit.

\section{Hasil Analisis Bivariat}

Kegiatan dalam penelitian ini meliputi perhitungan jumlah kematian jentik Aedes aegypti dengan pengaruh air rendaman kulit batang pepaya, setelah perlakuan. Proses pengamatan pada 36 jentik Aedes aegypti yang direndam dalam air rendaman kulit batang pepaya selama maksimal 5 menit, pada masing-masing larva yang mati maupun hidup, yang berada 
di dalam botol berisi masing-masing $50 \mathrm{ml}$ air rendaman kulit batang pepaya, maka didapatkan hasil seperti pada tabel berikut :

\section{Tabel 2. Pengaruh Air Rendaman Kulit Batang Pepaya terhadap}

\section{Kematian Jentik Aedes aegypti.}

Pengaruh Air Rendaman Kulit Batang Pepaya terhadap Kematian Jentik Aedes aegypti.

\begin{tabular}{|c|c|c|c|c|c|c|c|c|}
\hline \multirow{3}{*}{$\begin{array}{l}\text { Pemberian } \\
\text { Air } \\
\text { rendaman } \\
\text { kulit batang } \\
\text { pepaya }\end{array}$} & \multicolumn{6}{|c|}{ Kematian Jentik nyamuk Aedes aegypti } & \multirow[t]{3}{*}{ OR } & \multirow[t]{3}{*}{$p$} \\
\hline & \multicolumn{2}{|c|}{ Mati } & \multicolumn{2}{|c|}{ Hidup } & \multicolumn{2}{|c|}{ Total } & & \\
\hline & $\mathrm{n}$ & $\%$ & $\mathrm{n}$ & $\%$ & $\mathrm{n}$ & $\%$ & & \\
\hline & $\overline{34}$ & $\overline{94,4}$ & 2 & 15,5 & 36 & 100 & 4.10 & 0.043 \\
\hline Tidak & 0 & 0 & 36 & 100 & 36 & 100 & & \\
\hline
\end{tabular}

Hasil analisis bivariat berdasarkan tabel 2 diatas,menunjukkan bahwa kematian jentik Aedes aegypti dengan Nilai $p$ value $=0.043$, mempunyai pengaruh pemberian air rendaman kulit batang pepaya yang signifikan secara statistik dengan rendaman air rendaman kulit batang pepaya pada odds ratio $=4.10$ kali.

\section{PEMBAHASAN}

Berdasarkan hasil pengamatan yang dilakukan hasil uji coba air rendaman kulit batang pepaya dengan formulasi yang sama, menyebabkan jumlah kematian jentik yang berbeda dengan rentang waktu yang sama, hasil yang diperoleh sebagai berikut : 1) Pengaruh Kematian jentik Aedes Aegypti dengan air rendaman kulit batang pepaya hampir seluruh 34 dari 36 Jentik Aedes aegypti $(\mathrm{Ae})$ mati dalam air rendaman $50 \mathrm{ml}$ pada air rendaman kulit batang pepaya dalam waktu dibawah 1 menit.

Sependapat dari hasil penelitian Lilia Delli (2016) bahwa : Ada pengaruh pemberian ekstrak daun pepaya(Carica Papaya,Linn) terhadap mortalitas larva nyamuk Aedes aegypti Instra III.

Sependapat dengan Saraswati Putri Anggia, (2014) hasil penelitiannya : Ekstrak daun pepaya (Carica papaya L) memiliki potensi sebagai larvasida, dimana semakin tinggi konsentrasi ekstrak yang diberikan maka menimbulkan kematian yang tinggi terhadap larva nyamuk Aedes aegpti instars III.

Sejalan denga hasil penelitian, Suhartono Eko, dkk (2015) The results shows that the seed and peel extracts has a larvicidal activity against Aedes aegypti. The seed extracts has a higher larvicidal activity than peel extracts. This migh be de due the effect of pyhtochemical constituent in extract suc as flavonoid, alkaloid and tannin. From this study indicate that the aqueuous extracts of seed and peel of Carica papaya showed potential 
larvicidal activity for Aedes aegypti. Further studies might be needed for the used of this extracts for eco-friendly vector control programs especially for Aedes aegypti.

Sependapat dengan Ariesta Ayu Adhityas, (2009) hasil penelitiannya : Bahan alami dari larutan daun pepaya (Carica papaya) berpengaruh dalam membunuh larva nyamuk Aedes aegypti Instar II.

Sependapat dengan hasil penelitian Aji Rustam Rochmat (2017) Adanya pengaruh yang signifikan antara rendaman daun pepaya dengan keberadaan jentik Aedes aegipty pada lingkungan tempat penampungan air, dengan nilai $\mathrm{OR}=4.375$.

Sejalan hasil penelitian, Juhaerah La Taha Rasman, (2015) The results showed that papaya leaf extract, the first 15 minutes pulled all the mosquitoes in a cage and there is no death. At a concentration of 50\% LC50 is reached after 45 minutes on average Aedes aegypti dead reached 11 tails. LC50 at 60\% concentration is reached after 30 minutes on average Aedes aegypti dead reached 16 tails. LC50 at 70\% concentration is reached after 30 minutes on average observation Aedes aegypti dead reached 17 tails. This mosquito smell the papaya extract containing bitter substances karpain an insecticide plant alkaloid that is not favored by mosquitoes. Alkoloid karpain that has the characteristics of safe neurotoxin when inhaled by humans. As an insect neurotoxin exposure to toxins is generally experiencing spasms and paralysis before death. Conclusions research papaya extract is able to control the mosquito Aedes aegypti with standard LC50. Concentration of 60\% papaya extract more effective than a concentration of $50 \%$ and $70 \%$. It is recommended to people to take advantage of papaya leaf extract as an alternative vegetable insecticide.

Sependapat dengan hasil penelitian Ningsih Wilda Enis, (2000) kesimpulan penelitiannya : ekstrak daun Pepaya efektif sebagai larvasida terhadap nyamuk Anopheles Aconitus Donits,dalam Upaya Pencegahan Penyakit Malaria di Daerah Persawahan Desa Lalonggombu Kecamatan Andolo Kabupaten Konawe Selatan.

Sependapat dengan hasil penelitian Fadlilah Nur Angger Luhung,(2017) Simpulan hasil penelitiannya : Lotion ekstrak daun pepaya (Carica Papaya $L$ ) efektif menolak nyamuk Aedes Aegyptipada konsentrasi $30 \%$ karena daya tolaknya lebih dari $90 \%$.

Sependapat dengan Susilo Alvionita Patrysia (2013) hasil simpulan penelitiannya : Ekstrak daun pepaya (Carica Papaya L.)memiliki efek sebagai Larvasida Nyamuk Culex sp.

Sependapat dengan penelitian Tyas Dian Wahyuning,(2014), ekstrak daun pepaya (Carica papaya $L$ ) lebih efektif digunakan sebagai larvasida, berdasarkan pada besarnya LC 50 dari ekstrak daun pepaya (Carica papaya L)pada masa dedah 12 jam, 24 jam, 36 jam dan 48 jam, lebih rendah apabila dibandingkan dengan rebusan dan rendaman daun pepaya (Carica papaya $L$ ). 
Sejalan dengan hasil penelitian Vasugi Malathi, (2015) Phytochemical screening of the selected parts' crude aqueous and ethanol extracts indicated the presence of alkaloids, carbohydrates, saponin, phenol, tannin, flavones, coumarins, anthocyanin and flavanoidswhich are known to posses medicinal and insect larvicidal properties. Larvicidal effect of 2nd 4th instar larvae of mosquito species Aedesaegypti have been investigated for $24 \mathrm{hrs}$ with $1 \mathrm{mg} / \mathrm{ml}$ concentration of extracts of selected parts of Carica papaya. The results clearly indicated that there is a significant variation among the aqueous and ethanol extracts of the selected parts of the plant. The seed extracts are observed as effective larvicide than other selected parts of Carica papaya.

Sependapat dengan Manurung Rofirma,(2012) kesimpulan hasil penelitiannya : Semakin tinggi konsentrasi perasan daun pepaya (Carica Papaya Linn) maka semakin baik digunakan sebagai repellent.

Sependapat dengan hasil penelitian Swastika Deby , (2015) berikut kesimpulannya : Ekstrak Daun Pepaya (Carica Papaya Linn) berpengaruh terhadap Kematian Larva Nyamuk Aedes aegypti.

Simpulan peneliti bahwa rendaman kulit batang pepaya, diketahui bahwa hampir seluruh (94,4\%) ditemukan 34 larva mati dan tersisa 2 larva yang hidup dari jumlah 36 larva nyamuk Aedes aegypti $(\mathrm{Ae})$ dalam rebusan $50 \mathrm{ml}$ air rendaman kulit batang pepaya dalam waktu dibawah 1 menit.

Berdasarkan analisis Chi-square diperoleh nilai $P=0.04<\alpha 0.05$. Maka Ho ditolak dan Ha diterima yang berarti secara statistik ada pengaruh air rendaman kulit batang pepaya yang signifikan terhadap kematian jentik Aedes aegypti pada tempat penampungan air dengan Nilai $\mathrm{p}$ value $=0.043$, mempunyai pengaruh air rendaman kulit batang pepaya yang signifikan secara statistik dengan kematian jentik Aedes aegypti pada odds ratio $=4.10$ kali.

\section{SIMPULAN DAN SARAN}

Tumbuhan pepaya banyak mengandung zat yang disebut anzim papain, efek protease papain dapat membunuh jentik Aedes aegypti. Hasil analisis univariat menunjukkan bahwa hampir seluruh $(94,4 \%)$ ditemukan 34 jentik mati dan tersisa 2 jentik yang hidup dari jumlah 36 jentik Aedes aegypti $(\mathrm{Ae})$ dalam air rendaman kulit batang pepaya $50 \mathrm{ml}$ dalam waktu dibawah 1 menit. Hasil analisis bivariat, menunjukkan bahwa dengan Nilai $p$ value $=0.043$, mempunyai pengaruh air rendaman kulit batang pepaya yang signifikan secara statistik dengan rendaman air rendaman kulit batang pepaya pada odds ratio $=4.10$ kali.

Saran dari penelitian ini adalah Pemberantasan jentik Aedes aegypti, solusinya agar masyarakat secara aktif membiasakan membuat air rendaman kulit batang pepaya dan menuangkan kedalam tempat penampungan air sesuai kebutuhan. 


\section{DAFTAR PUSTAKA}

Aji Rustam Rochmat, (2017) Pengaruh Serai Wangi terhadap Keberadaan larva Jentik Aeges aegypti pada Tempat Penampungan Air.JVK.3 (1) (2017) hlm.1-4. http://ejournal poltekkes-pontianak.ac.id/index.php/JVK.

Ancani Niluh Komang Sumi, (2016) Efektifitas Ekstrak Etanol Serai Wangi (Cymbopogon Nardus L) sebagai Larvasida Aedes aegypti.

Astriani Yoke, (2016) Potensi Tanaman di Indonesia sebagai Larvasida Alami untuk Aedes aegypti. SPIRAKEL, Vol.8.No.2, Bulan Desember 2016: hal.37-46.

Ariesta Ayu Adhityas, (2009) Uji Efektifitas Larutan Daun Pepaya (Carica papaya) Sebagai Larvasida terhadap Kematian Larva Nyamuk Aedes aegypti Di Laboratorium B2P2VRP.Fakultas Kesehatan Universitas Dian Nuswanto.Semarang.

Fadlilah Nur Angger Luhung, dkk (2017) Uji Daya Ekstrak Daun Pepaya (Carica Papaya L) dalam Sediaan Lotion dengan Basis PEG400 sebagai Repellent terhadap Aedes Aegypti. Jurnal IImu Kesehatan Masyarakat. FIK Universitas Negeri Semarang. (online) Vol.5, No.3, diakses 01-November 2017).

Juhaerah La Taha Rasman, ( 2015) Ability of Papaya Leaf Extract (Carica papaya) in Controlling Aedes aegypti Mosquito (Experimental Study) International Journal of Science : Basic and Applied Research (IJSBAR) 2015.Vol.24.NO.3.pp 164172.Lecturer of Health Polytechnic, Ministry of Health makassar, Indonesia.

Lilia Delli (2016) Pengaruh Ekstrak Daun Pepaya (Carica Papaya,Linn) Terhadap Mortalitas Larva Nyamuk Aedes aegypti Instra III Batu Raja Kabupaten OKU. Program Study: Ilmu Kesehatan Masyarakat. Sekolah Tinggi Ilmu Kesehatan Al-Ma'arif Baturaja.

Manurung Rofirma,dkk (2010) Pengaruh Daya Tolak Perasan Serai Wangi (Cymbopogon Nardus) terhadap Gigitan Nyamuk Aedes aegypti. Fakultas Kesehatan masyarakat Universitas Sumatera Utara.

Manurung Rofirma, dkk (2012) Pengaruh Daya Tolak Perasan Serai Wangi (Cymbopogon Nardus) terhadap Gigitan Nyamuk Aedes aegypti. Departemen Kesehatan Lingkungan. Fakultas Kesehatan Masyarakat. Universitas Sumatera Utara. Medan.

Ningsih Wilda Enis, dkk (2000) Efektifitas Uji Daya Bunuh Ekstrak Daun Pepaya (Carica Papaya L.) terhadap Larva Nyamuk Anopheles Aconitus Donits dalam Upaya Pencegahan Penyakit Malaria di Daerah Persawahan Desa Lalonggombu Kecamatan Andolo Kabupaten Konawe Selatan. Fakultas Kesehatan Masyarakat Universitas Halu Oleo. 
Nugroho Arif Dwi, (2011) Kematian larva Aedes aegypti setelah Pemberian Abate di bandingkan dengan pemberian serbuk serai.KESMAS..7 (1) (2011) 9196.http://Journal.unnes.ac.id/index.php/kemas.

Pratiwi Amelia, (2014) Studi Diskriptif Penerimaan Masyarakat terhadap Larvasida Alami.UJPH.3 (2) (2014) hal 1-10. http://journal.unnes.ac.id/sju/index.php/ujph.

Saraswati Putri Anggia, dkk (2014) Uji Potensi Ekstrak Daun Pepaya (Carica papaya L) Sebagai Larvasida terhadap Larva Aedes aegpti instars III. Jurusan Biologi FMIPA Universitas Lampung.

Suhartono Eko, dkk (2015) Aqueous Extracts of Seed and Peel of Carica Papaya Against Aedes aegypti. Journal of Medical and Bioengireering Vo.4.No.5.October.2015.Departement of Medical Pharmacology Faculty of Medicine Lambung Mangkurat University. Banjarmasin.Indonesia.

Susilo Alvionita Patrysia, dkk (2013) Efek Ekstrak Daun Pepaya (Carica Papaya L.) sebagai Larvasida Nyamuk Culex sp.Bagian parasitologi Fakultas Kedokteran Universitas Maranatha Bandung.

Swastika Deby , (2015) Pengaruh Ekstrak Daun Pepaya (Carica Papaya Linn) terhadap Kematian Larva Nyamuk Aedes aegypti. Sekolah Tinggi IImu Farmasi. Jurnal Publikasi Kesehatan Masyarakat Indonesia, Vol.2 No.2, hal: 84-87, Agustus 2015.

Tyas Dian Wahyuning, dkk (2014), Perbedaan Toksisitas Ekstrak, Rebusan dan Rendaman Daun Pepaya (Carica papaya L) terhadap Mortalitas Larva Nyamuk Aedes aegypti L. Program Studi Biologi FKIP Universitas Jember.

Vasugi Malathi, (2015) Evaluation of mosquito larvicidal effect of carica papaya against Aedes aegypti. International Journal of Mosquito Research,2015;2(3):21-24. Departement of Zoology Periyar.E.V.R Cpollege (Autonomous) Thiruchirappalli23. Tamil Nadu.India.PT and Research. 